\title{
Mesenchymal Stem Cells: The New Players in the Pathogenesis of Tuberculosis
}

\section{Rahul Mittal*}

Division of infectious Diseases, Childrens Hospital Los Angeles, Los Angeles, CA 90027 USA

Tuberculosis (TB) is the most common and deadly infectious disease associated with significant mortality and morbidity $[1,2]$. $\mathrm{TB}$ is the second highest cause of mortality from an infectious agent accounting for 2 million deaths each year [3]. There are more than 9 million new cases of TB every year worldwide, and incidence is declining only at a rate of less than 1\% per year [4]. Mycobacterium tuberculosis $(M . t b)$ is the causative agent of TB, which is transmitted through aerosol droplets that are inhaled by the host and deposited in the lung which become the reservoir of infection [5-7]. A recent surge in the antibiotic resistant strains of $M$. $t b$ has further complicated the treatment of this deadly disease [8-11]. Lack of understanding about the pathogenesis of the disease has hindered the development of effective preventive strategies against this fatal disease.

Raghuvanshi et al. [12] recently reported that Mesenchymal stem cells (MSCs) play a crucial role in ability of $M$. $t b$ to evade potent host immune responses and cause TB. MSCs are multipotent stem cells that can differentiate into a variety of cell types, including osteoblasts (bone cells), chondrocytes (cartilage cells) and adipocytes (fat cells) [13-15]. Employing a mouse model of $M$. $t b$ infection, these workers demonstrated that splenocytes from these infected mice show profoundly reduced proliferation in response to the $\mathrm{T}$ cell mitogen Con A indicating immune suppression. Using a series of experiments these workers confirmed that inhibition of $\mathrm{T}$ cells is mediated by accessory cells and not restricted to polyclonal activation of T cells. These workers identified that majority of these accessory cells express stem cell antigen Sca-1 that is characteristic of the stem cell lineage. These cells also express CD29, CD44, and Flk-1 but did not express CD34, CD45, $\mathrm{CD} 11 \mathrm{~b}, \mathrm{CD} 11 \mathrm{c}$ and Gr1 that are the signature membrane markers of MSCs. In addition these cells readily differentiate into adipocytes confirming their identity as bonafide MSCs. To further confirm the role of MSCs in the pathogenesis of TB, these workers reconstituted TGF $\beta$ RIIDN mice, that are resistant to $M$. $t b$ infection, with MSCs isolated from infected mice and then infected with $M$. $t b$. Interestingly reconstituted TGF $\beta$ RIIDN mice were susceptible to $M$. $t b$ infection whereas control TGF $\beta$ RIIDN animals that did not receive any cells or received adherent spleen cells did not get TB. MSCs were observed to surround the $M$. $t b$ organisms, which might help in confining them within granuloma like structures. At par with these observations in mouse model, these workers also demonstrated that MSCs surround granuloma of human patients with TB.

Another intriguing finding that these workers observed during this study is that nitric oxide (NO) plays an important role in the recruitment of these MSCs at the site of granulomas. However immune suppression mediated by these MSCs was independent of IL-6 as addition of anti-IL-6 was unable to overcome the blockade in splenocyte proliferation. MSCs have earlier been shown to play an important role in the regulation of immune responses in Crohn's disease, and in tumors by migrating to the inflammation sites [16-21] but so far their role in TB has not been elucidated. This study by Raghuvanshi et al. [12] is the first novel observation that MSCs play a detrimental role in the pathogenesis of TB.
In summary these workers observed that "large numbers of MSCs infiltrate into the site of tuberculosis infection and position themselves between the harbored pathogens and effector $\mathrm{T}$ cells that target the pathogens". These workers concluded that "MSCs inhibit cellular immune responses, which contributes to the establishment of persistent M. $t b$ infection". These interesting findings reported by the team of Gobardhan Das will definitely open up avenues for the treatment of TB, which affects about one third of the human population. The recruitment of MSCs create immunosuppressive environment by preventing proliferation of T cells hence preventing the killing of $M$. $t b$ by these potent immune cells. Therefore targeting MSCs or NO seems a plausible therapeutic intervention for the design of new effective preventive strategies against TB.

\section{References}

1. Furlow B (2010) Tuberculosis: a review and update. Radiol Technol 82: 33-52.

2. Barnes PF, Cave MD (2003) Molecular epidemiology of tuberculosis. N Engl Med 349: 1149-1156.

3. Currey B, Quamruzzaman Q, Rahman M (2011) A millennial cover-up tuberculosis deaths in South Asia. J R Soc Med 104: 2-4.

4. WHO, Global tuberculosis control: a short update to the 2009 report. WHO/ HTM/TB/2009426, World Health Organization, Geneva (2009)

5. Hanekom WA, Lawn SD, Dheda K, Whitelaw A (2010) Tuberculosis research update. Trop Med Int Health 15: 981-989.

6. Tiruviluamala P, Reichman LB (2002) Tuberculosis. Annu Rev Public Health 23:403-426.

7. lademarco MF, Castro KG (2003) Epidemiology of tuberculosis. Semin Respir Infect 18: 225-240.

8. Dheda K, Warren RM, Zumla A, Grobusch MP (2010) Extensively drug resistant tuberculosis: epidemiology and management challenges. Infect Dis Clin North Am 24: 705-725.

9. Banerjee R, Schecter GF, Flood J, Porco TC (2008) Extensively drug-resistan tuberculosis: new strains, new challenges. Expert Rev Anti Infect Ther 6: 713724

10. Shenjie T, Qing Z, Jinming Y, Yidian L, Wei S, et al. (2011) Extensively drug resistant tuberculosis at a tuberculosis specialist hospital in Shanghai, China: Clinical characteristics and treatment outcomes. Scand J Infect Dis (In Press).

*Corresponding author: Rahul Mittal, Division of Infectious Diseases, MS\#51,,Childrens Hospital Los Angeles, 4650 Sunset Boulevard, Los Angeles, CA 90027, USA, Tel.: +1 323-361-5809; E-mail: ramittal@chla.usc.edu

Received February 03, 2011; Accepted February 10, 2011; Published April 29, 2011

Citation: Mittal R (2011) Mesenchymal Stem Cells: The New Players in the Pathogenesis of Tuberculosis. J Microbial Biochem Technol 3: ii-0. doi:10.4172/1948-5948.100000e3

Copyright: @ 2011 Mittal R. This is an open-access article distributed under the terms of the Creative Commons Attribution License, which permits unrestricted use, distribution, and reproduction in any medium, provided the original author and source are credited. 
Citation: Mittal R (2011) Mesenchymal Stem Cells: The New Players in the Pathogenesis of Tuberculosis. J Microbial Biochem Technol 3: ii-0. doi:10.4172/1948-5948.100000e3

11. Becerra MC, Appleton SC, Franke MF, Chalco K, Arteaga F, et al. (2011) Tuberculosis burden in households of patients with multidrug-resistant and extensively drug-resistant tuberculosis: a retrospective cohort study. Lancet 377: 147-152.

12. Raghuvanshi S, Sharma P, Singh S, Van Kaer L, Das G (2010) Mycobacterium tuberculosis evades host immunity by recruiting mesenchymal stem cells. Proc Natl Acad Sci U S A 107: 21653-21658.

13. Uccelli A, Moretta L, Pistoia V (2008) Mesenchymal stem cells in health and disease. Nat Rev Immunol 8: 726-736.

14. Liu ZJ, Zhuge Y, Velazquez OC (2009) Trafficking and differentiation of mesenchymal stem cells. J Cell Biochem 106: 984-991.

15. Shi Y, Hu G, Su J, Li W, Chen Q, et al. (2010). Mesenchymal stem cells: a new strategy for immunosuppression and tissue repair. Cell Res 20: 510-518.

16. Panés J, Ordás I, Ricart E (2010) Stem cell treatment for Crohn's disease. Expert Rev Clin Immunol 6: 597-605.
17. González MA, Gonzalez-Rey E, Rico L, Büscher D, Delgado M (2009) Adiposederived mesenchymal stem cells alleviate experimental colitis by inhibiting inflammatory and autoimmune responses. Gastroenterology 136: 978-989.

18. Ryu CH, Park SH, Park SA, Kim SM, Lim JY, et al. (2011) Gene Therapy of Intracranial Glioma using Interleukin 12-secreting Human Umbilical Cord Blood-derived Mesenchymal Stem Cells. Hum Gene Ther (in press).

19. Klopp AH, Gupta A, Spaeth E, Andreeff M, Marini F 3rd. (2011) Concise review: dissecting a discrepancy in the literature: do mesenchymal stem cells support or suppress tumor growth? Stem Cells 29: 11-19.

20. García-Gómez I, Elvira G, Zapata AG, Lamana ML, Ramírez M, et al. (2010) Mesenchymal stem cells: biological properties and clinical applications. Expert Opin Biol Ther 10: 1453-1468.

21. Bergfeld SA, DeClerck YA (2010) Bone marrow-derived mesenchymal stem cells and the tumor microenvironment. Cancer Metastasis Rev 29: 249-261.

\section{Submit your next manuscript and get advantages of OMICS Group submissions}

Unique features:

- User friendly/feasible website-translation of your paper to 50 world's leading languages

- Audio Version of published paper

Digital articles to share and explore

Special features:

- 100 Open Access Journals

10,000 editorial team

21 days rapid review process

Quality and quick editorial, review and publication processing

Indexing at PubMed (partial), Scopus, DOAJ, EBSCO, Index Copernicus and Google Scholar etc

- Sharing Option: Social Networking Enabled

- Authors, Reviewers and Editors rewarded with online Scientific Credits

- Befter discount for your subsequent articles

Submit your manuscript at: http://www.editorialmanager.com/imbt 